in vivo $35: 1365-1377(2021)$

doi:10.21873/invivo.12389

Review

\title{
Radiotherapy and Renal Cell Carcinoma: A Continuing Saga
}

\author{
DESPOINA SPYROPOULOU ${ }^{1}$, PANAGIOTIS TSIGANOS ${ }^{2}$, FOTEINOS-IOANNIS DIMITRAKOPOULOS ${ }^{3,4}$, \\ MARIA TOLIA ${ }^{5}$, ANGELOS KOUTRAS ${ }^{3}$, DIMITRIS VELISSARIS ${ }^{6}$, MARIA LAGADINOU ${ }^{7}$, \\ NIKOLAOS PAPATHANASIOU ${ }^{8}$, ARETI GKANTAIFI ${ }^{9}$, HARALABOS KALOFONOS $^{3}$ and DIMITRIOS KARDAMAKIS ${ }^{1}$ \\ ${ }^{1}$ Department of Radiation Oncology, University of Patras Medical School, Patras, Greece; \\ ${ }^{2}$ Clinical Radiology Laboratory, Department of Medicine, University of Patras, Patras, Greece; \\ ${ }^{3}$ Division of Oncology, Department of Medicine, University Hospital of Patras, Patras, Greece; \\ ${ }^{4}$ Clinical and Molecular Oncology Laboratory, Medical School, University of Patras, Patras, Greece; \\ ${ }^{5}$ Radiotherapy Department, University Hospital Heraklion, University of Crete Medical School, Heraklion, Greece; \\ ${ }^{6}$ Emergency Department and Internal Medicine Department, University Hospital of Patras, Patras, Greece; \\ ${ }^{7}$ Emergency Department University Hospital of Patras, Patras, Greece; \\ ${ }^{8}$ Nuclear Medicine and PET/CT Department, University Hospital of Patras, Patras, Greece; \\ ${ }^{9}$ Radiotherapy Department, Interbalkan Medical Center, Thessaloniki, Greece
}

\begin{abstract}
Renal cell carcinoma (RCC) is one of the most aggressive malignancies of the genito-urinary tract, having a poor prognosis especially in patients with metastasis. Surgical resection remains the gold standard for localized renal cancer disease, with radiotherapy $(R T)$ receiving much skepticism during the last decades. However, many studies have evaluated the role of $R T$, and although renal cancer is traditionally considered radio-resistant, technological advances in the $R T$ field with regards to modern linear accelerators, as well as advanced RT techniques have resulted in breakthrough therapeutic outcomes. Additionally, the combination of RT with immune checkpoint inhibitors and targeted agents may maximize the clinical benefit. This review article focuses on the role of $R T$ in the therapeutic management of renal cell carcinoma.
\end{abstract}

Renal cell carcinoma (RCC) is the most common and aggressive neoplasm of the kidney. It accounts for $3 \%$ of all adult cancers and over $90 \%$ of kidney cancers (1). The

This article is freely accessible online.

Correspondence to: Ass. Prof. Despoina Spyropoulou, MD, Department of Radiation Oncology, University of Patras Medical School, University Campus, 26504 Patras, Greece. Tel: +30 6945970107, e-mail: spyrdespina@upatras.gr

Key Words: Renal cell cancer, radiotherapy, radioresistance, radiosensitivity, oligometastatic disease, stereotactic body radiation therapy, review. incidence of RCC increases with age; almost $75 \%$ of patients are over 60 years of age, while $70-75$ is the most predominant age group and a rarity is under 50 (2). Well established risk factors include cigarette smoking, hypertension, obesity and genetic susceptibility (3).

RCC has a variable histologic appearance with three different cell types accounting for more than $90 \%$ of all cancers (4). The cell types include: 1) clear cell, 2) granular cell, 3) spindle cell or sarcomatoid variant. Among these cell types the most frequent is clear cell renal carcinoma that constitutes almost $75 \%$ of all tumors (5).

A significant number of cases with RCC may be asymptomatic with the tumor being an incidental finding in a routine radiological examination. The most frequent clinical signs of RCC known as the "classic triad" are gross or microscopic hematuria, intermittent recurrent pain and flank mass. These signs appear in almost $10 \%$ of patients and are suggestive of advanced disease. Some patients may experience signs and symptoms related to local mass or systemic paraneoplastic syndromes. It is estimated that almost half RCC are incidentally found during a routine radiological investigation such as magnetic resonance imaging, computed tomography or ultrasound, mainly for the upper abdomen and liver.

The most important prognostic factors in RCC are related to the a) gross anatomic extent of the primary renal lesion, b) nuclear grade, c) perinephric extension, d) renal vein extension, e) lymph node involvement and f) presence of distant metastasis at the time of diagnosis.

If RCC is detected at an early stage, the primary treatment is surgical. However, approximately $25 \%$ of patients may 
eventually develop distant metastases even after local therapy with complete surgical resection $(6,7)$. Although renal metastatic cancer is related to poor prognosis, newer systematic treatment approaches (i.e. immunotherapy) have improved the prognosis of these patients. However, eventually, only $2 \%-20 \%$ of patients suffering from metastases will experience a prolonged survival (8).

Historically, RCC was considered a radio-resistant tumor (9), with RT being applied mostly to alleviate symptoms of locally advanced or metastatic disease (i.e. painful bone metastases). However, modern RT techniques such as intensity modulated radiation therapy (IMRT), volumetricmodulated arc therapy (VMAT) and stereotactic body radiation therapy (SBRT) are promising techniques that can provide both effective local control (LC) and palliation of metastatic symptoms with low toxicity of the surrounding normal tissues.

\section{General Treatment Modalities of RCC}

Traditionally, surgery including partial and radical nephrectomy has been the standard of care with proved efficacy to treat patients with localized, unilateral RCC with no evidence of distant metastasis.

While radical nephrectomy involves complete resection of Gerota's fascia, including the kidney and the ipsilateral adrenal gland, partial nephrectomy - a less invasive method -, is preferred for patients suffering from unilateral stages I-III RCC, familial RCC, uninephric state or bilateral renal tumors. Partial nephrectomy results in increased renal function and reduced overall mortality compared to radical nephrectomy (10).

However, despite the curative intent of surgical resection, it is estimated that almost $30 \%$ of the patients will experience a relapse of renal cancer (11). Relapses are usually metastatic, with metastases mostly to the lung, bone, and brain while recurrences to the ipsilateral or contralateral kidney are rare. Cancer relapse is strongly related to tumor stage, nodal stage, tumor grade and performance status of the patient.

Elderly and frail patients suffering from medical comorbidities or chronic kidney disease may not be suitable for surgical treatment and need to be given alternative treatment options. This includes stereotactic ablative RT, a highly conformal technique with tolerable side effects (12). Furthermore, elderly patients with renal cancer and tumors up to $4 \mathrm{~cm}$ having limited life expectancy due to comorbidities, may be candidates for active surveillance as RCC is a slowly growing tumor with a low metastatic rate $(13,14)$.

Adjuvant and systemic treatment options include immunotherapeutics, angiogenesis-related drugs such as sunitinib, pazopanib and bevacizumab as well as inhibitors of mTOR (Mammalian Target of Rapamycin), such as everolimus and temsirolimus $(15,16)$.

\section{Radiotherapy of RCC}

In the past decades, renal tumors were considered radioresistant (17). This was explained by both in vitro and in vivo studies. In a meta-analysis, Deschavanne et al. evaluated the in vitro radiosensitivity of several cancer cell types. The authors found that RCC cells were the most radioresistant (9). In vivo studies compared sphingomyelinase-knockout mice with wild type mice and have shown that the former had a higher threshold to irradiation-induced endothelial apoptosis while being radioresistant to a single-dose RT of 20 Gy (18). However, a thorough research of the current literature reveals not only studies showing relative radiation resistance but also publications demonstrating radiation sensitivity of renal cancer cells $(19,20)$.

Furthermore, RCC is known to have a lower $\alpha / \beta$ coefficient of the linear- quadratic model (21) and thus, higher doses per fraction are needed to achieve better LC. Therefore, hypofractionated RT (single or a few fractions, with higher dose per fraction) or SBRT can be used alternatively, in order to overcome the radioresistance of $\mathrm{RCC}$. The biological rationale of RCC radiosensitivity to SBRT, is based on the ceramide pathway, which is activated with the delivery of higher dose per fraction. SBRT can also induce an abscopal effect which represents the capacity of higher, ablative doses to stimulate antitumor immunity. RCC radiosensitivity can be enhanced in novel combinations of SBRT and targeted therapies (22).

In a retrospective study, Correa et al. (23) examined the role of stereotactic ablative radiotherapy (SABR) for large renal tumors. The study included 11 patients and SABR was delivered either to the tumor or to the whole kidney, with a total dose of 25 to $40 \mathrm{~Gy}$ in five fractions. The median tumor diameter and planning target volume were $9.5 \mathrm{~cm}$ and $819.3 \mathrm{~cm}^{3}$, respectively. It was concluded that SABR was an effective treatment with minimal toxicity. The role of SABR is under continuing investigation, in a phase II clinical trial, in order to evaluate its efficacy for the treatment of primary RCC (24).

Grubb et al. (25) implemented a dose escalation protocol of SBRT in 11 poor surgical candidates with localized RCC. They employed three dose levels at 48 Gy, 54 Gy and 60 Gy, all in three fractions. They concluded that SBRT was safe and well tolerated. However, the determination of a dose threshold for tumor control was not established.

\section{Preoperative RT}

Preoperative RT can be a treatment option in selected patients with locally advanced marginally operable renal cancer. Juusela et al. (26), in a study during 1968-1972, evaluated the effect of preoperative RT on the survival of patients with renal adenocarcinoma. The study included 88 
patients of whom 38 underwent preoperative RT for a total dose of 3,300 rads (33 Gy) in 3 weeks with daily fractions of 220 rads, followed by extrafascial nephrectomy 3 weeks after RT completion, with the remaining patients undergoing an extrafascial nephrectomy immediately after the end of radiotherapy. RT was given with $33 \mathrm{MeV}$ photons from a Betatron. Oblique opposed anterior and posterior radiation fields were used, with an adequate margin in order to safely cover the entire renal tumor mass. The actuarial 5-year survival was $47 \%$ in patients undergoing preoperative RT, and $63 \%$ in those undergoing only nephrectomy. The study concluded that the addition of preoperative RT did not show any benefit on the 5-year prognosis (26).

Another study from Rotterdam by van der Werf-Messing (27) showed no positive effect with respect to overall survival (OS) from preoperative RT versus upfront surgery. Patients included to the trial were diagnosed with kidney carcinoma based on intravenous pyelography and arteriography. Renal cancer patients were treated either by nephrectomy or by preoperative RT for a total dose of $30 \mathrm{~Gy}$ in 15 fractions, immediately followed by nephrectomy. The radiation field included the area of the involved kidney plus regional lymph nodes. The study concluded that the addition of preoperative RT did not improve the 5-year prognosis of renal cancer patients.

In another study by Frydenberg et al. (28) from Mayo Clinic, the role of preoperative external beam RT followed by debulking surgery and intraoperative electron RT for locally advanced primary or recurrent renal cancer was evaluated. The study included 9 patients with locally recurrent disease and 2 patients with remaining renal cancer following nephrectomy. They received 45 to $50.40 \mathrm{~Gy}$ in 1.8 Gy fractions in preoperative external RT, followed by maximal surgical debulking and intraoperative electron RT. Preoperative external RT was delivered with multiple field techniques in the nine patients that had not previously undergone RT. The RT fields used were antero-posterior and postero-anterior plus lateral and oblique, in order to protect the spinal cord. Patients with RCC experienced minimal side effects. Four out of eight patients suffered no treatmentrelated toxicity and three of the remaining four experienced grade 1 or 2 toxicity, related to surgery or external RT. The study concluded that selected patients with local recurrent or persistent disease after radical nephrectomy may be positively affected by undergoing an aggressive local treatment approach through preoperative and intraoperative RT followed by maximal surgical debulking.

\section{Intraoperative $\mathbf{R T}$}

Intraoperative RT (IORT) refers to a RT technique which delivers a single dose of radiation to a limited renal volume immediately after tumor resection, avoiding unnecessary irradiation of normal surrounding tissues. The efficacy of IORT in managing renal cancer has been evaluated in several studies with patients having locally advanced or recurrent renal cancer. Paly et al. evaluated the role of this technique in a multi-institutional cohort of 98 patients with advanced or recurrent RCC (29). IORT was delivered during nephrectomy in patients with advanced disease, or during surgical resection of locally recurrent renal cancer in the renal fossa. The median IORT dose was $15 \mathrm{~Gy}$ with a range of 9.5-20 Gy. Eighty-seven percent of the patients underwent complete surgical resection of their tumor. Preoperative or postoperative external RT was delivered to $27 \%$ and $35 \%$ of patients, respectively. The study reported that the 5-year OS was $37 \%$ for patients with advanced disease and $55 \%$ for those with locally recurrent disease, with an overall $29 \%$ perioperative complication rate. OS at 1 and 5 years after IORT was $69 \%$ and $37 \%$ for patients with advanced renal cancer disease and $94 \%$ and $55 \%$ for patients with locally recurrent disease, respectively. Disease-specific survival (DSS) at 1 and 5 years was $72 \%$ and $41 \%$ for patients with advanced renal cancer disease and $96 \%$ and $60 \%$ for patients with locally recurrent renal cancer, respectively. Disease-free survival (DFS) at 1 and 5 years was $72 \%$ and $39 \%$ for patients with advanced renal cancer and $96 \%$ and $52 \%$ for patients with locally recurrent renal cancer, respectively. The study concluded that IORT improved the disease-free specific survival in patients with advanced or recurrent renal cancer without evidence of distant metastases.

Another study by Habl et al. (30) showed that intraoperative electron RT (IOERT) followed by external beam RT in patients with locally recurrent renal cancer improved LC rates. Although low toxicity was mentioned, this approach did not improve progression-free and OS. The study included 17 patients with histologically confirmed locally recurrent renal cancer disease in the renal fossa. These patients were treated by surgery and IOERT boost, with or without the addition of postoperative external RT. The dose of IOERT was prescribed to the $90 \%$ isodose line and the IOERT field included the anatomic area of the suspected microscopic spread. The selection of the electron energy was based on the depth of the tissue to be irradiated. The median electron energy used was $8 \mathrm{MeV}$ and the median dose of IOERT was $15 \mathrm{~Gy}$. Out of the 17 patients of the study, 11 patients also underwent postoperative 3Dconformal external beam RT (EBRT) with a median dose of 40 Gy with conventional fractionation.

Calvo et al. (31) evaluated the role of IOERT in renal cancer patients with locally advanced or recurrent renal cancer and have found good LC results and acceptable toxicity. However, the 5-year distant metastasis-free survival rate was $22 \%$. The study included 25 patients with pathologically proven locoregional advanced primary and recurrent renal cancer who were treated with maximal 
surgical resection and IOERT with or without the addition of perioperative EBRT. IOERT was applied in a single fraction and the radiation dose chosen was dependent on the amount of the residual disease, the presence of critical structures within the radiation field, and the dose of preoperative and/or anticipated postoperative external RT.

Another study at Mayo Clinic (32) including 22 renal cancer patients that were treated by maximal surgery resection and IOERT as well as adjuvant external RT has shown that the addition of IORT improved DFS. The study included 22 patients with locoregional recurrent renal cancer or locoregional advanced primary disease. Twenty-one patients that had not undergone prior RT underwent perioperative EBRT, either preoperatively, postoperatively or by combining both. One patient who had undergone RT in the past was not given perioperative EBRT. Surgical treatment was with negative margins (R0) in 5 patients and with residual microscopic disease (R1) in 17 patients. The median dose of IOERT that was applied was $12.5 \mathrm{~Gy}$. The observed OS and DFS at 1.5 and 10 years were $91 \%, 40 \%$, and $35 \%$ and $64 \%, 31 \%$, and $31 \%$, respectively. Recurrence within the IOERT field, locoregional relapse and distant metastases at 5 years were $9 \%, 27 \%$, and 64\%, respectively. Five patients suffered from acute or late toxicity. The study concluded that a multimodality treatment strategy consisting of perioperative EBRT, maximal surgical resection, and IOERT for patients with locoregional recurrent disease or locoregional advanced primary disease was associated with a low rate of locoregional recurrence. Toxicity was acceptable and long-term survival was achieved in a significant number of patients.

\section{Postoperative RT}

The value of postoperative RT has been evaluated in both prospective and retrospective studies but is still unclear. Kjaer et al. $(33,34)$ evaluated the role of adjuvant RT after nephrectomy in 65 patients, 34 with Stage II and 31 with Stage III renal adenocarcinoma. Patients were randomized to either undergo postoperative RT to the kidney bed and to the regional lymph nodes or to not undergo any postoperative treatment. Two types of RT techniques were used by the two oncological departments. One technique was a 3-field technique with one anterior wedge-filter port, and two lateral ports. The other technique included opposing ports during the first 10 fractions while the rotation technique was used for the remaining 10 fractions. The follow-up period in both arms of the study lasted until renal cancer relapse, death, or 5 years after surgery. Thirty-three patients did not undergo RT after nephrectomy and 32 patients underwent RT of a total dose of $50 \mathrm{~Gy}$, in $2.5 \mathrm{~Gy}$ per fraction. The overall 5-year survival mentioned in the group that did not undergo RT was $63 \%$ vs. $38 \%$ in the group that underwent RT treatment. The relapse rate was $43 \%$ in both groups. Patients who received RT suffered from significant side effects in the stomach, duodenum or liver that resulted in higher mortality rates.

Another retrospective study of 147 patients with histologically proven RCC treated between 1977 and 1988 by Stein et al. (35) evaluated the role of postoperative RT of a median total dose of $46 \mathrm{~Gy}$ in 56 patients with RCC. RT techniques included parallel opposing portals or the multiple field technique. The 5- and 10-year survival in patients who underwent RT were 50 and 44\%, respectively; in patients that did not undergo RT these were 40 and $32 \%$, respectively. Severe toxicity was presented in three patients $(5 \%)$ developing radiation-induced small bowel obstruction that was treated surgically. The study concluded that the addition of postoperative RT could reduce the local recurrence rate in RCC patients staged T3N0M0. Furthermore, it was also recommended that the surgical scar should always be included in the radiation field and receive a full dose radiation treatment.

A meta-analysis by Tunio et al. (36) from seven randomized controlled trials, including 735 patients and focusing on the efficacy of postoperative RT regarding OS, DFS and local relapse rates, showed that postoperative RT reduced the rate of local relapse but did not have any effect on DFS and OS. Overall toxicity was not significant, with manageable side-effects. However, this meta-analysis had important limitations such as the old RT techniques used (trial period between 1968 and 1999) and the not wellstandardized treatment doses and follow-up periods. Data from the above studies are summarized in Table I.

\section{Palliative RT in Metastatic RCC}

It is estimated that almost 1 in 4 RCC patients will suffer from metastatic disease, while $20-30 \%$ will present with metastatic relapse after surgery for localized disease (37). The most common metastatic sites include the liver, lungs, bones, brain and lymph nodes. Although RCC patients have a significant risk of local and metastatic relapse, there are no existing randomized trials to guide the optimal treatment options for these patients. However, even though patients with metastatic disease have a poor prognosis with a 5-year survival of $0 \%$ $18 \%$ (38), subsets of patients eventually show good outcomes with 5-year OS rates of more than 70\% (39).

Surgery was the first treatment option, in the presence of a single brain metastatic lesion, showing effective results, with longer disease-free intervals. However, surgical treatment was associated with higher complication rates of approximately $45.7 \%$ (40). Additionally, whole brain RT (WBRT) had been the standard of care for these patients; however, apart from the neurotoxicity that can be delivered by WBRT, studies have revealed disappointing results regarding OS as well (41-46). 
Table I. Non-metastatic RCC studies included in this review.

\begin{tabular}{|c|c|c|c|c|c|c|c|}
\hline Reference & Year & Patients ? & Treatment phase & Study design & Schedule & Outcome & Toxicity \\
\hline Correa et al. (23) & 2018 & 11 & Inoperable & Retrospective & $\begin{array}{l}25-40 \text { Gy in } \\
5 \text { fractions }\end{array}$ & $\begin{array}{c}\text { OS: median, 6-mo, } \\
1-\mathrm{y}, 2-\mathrm{y}, 3-\mathrm{y} \text { is } 20.4 \mathrm{mo}, \\
72.7 \%, 53 \%, 53 \% \\
35.4 \% \text { respectively }\end{array}$ & $\begin{array}{l}5 \text { G1 (fatigue, dyspnea, } \\
\text { nausea, diarrhea), } \\
1 \text { G2 (diarrhea) } \\
\text { and G3 (nausea) }\end{array}$ \\
\hline Grubb et al. (25) & 2021 & 11 & Inoperable & Prospective & $\begin{array}{l}48-60 \text { Gy in } \\
3 \text { fractions }\end{array}$ & $3-y \mathrm{LCR}=90 \%$ & G1 fatigue, nausea \\
\hline Juusela et al. (26) & 1977 & 38 & Preoperative & Prospective & $\begin{array}{l}3300 \text { rads in } \\
3 \text { weeks }\end{array}$ & 5 -y survival $=47 \%$ & Not stated \\
\hline Van der Werf-Messing (27) & 1973 & 116 & Preoperative & Prospective & $\begin{array}{c}\text { Total } 30 \text { Gy in } \\
15 \text { fractions }\end{array}$ & $\begin{array}{l}\text { No improvement in } \\
5 \text {-year prognosis }\end{array}$ & Not stated \\
\hline Frydenberg et al. (28) & 1994 & 8 & Preoperative & Prospective & $\begin{array}{l}\text { 45-50.4 Gy in } \\
1.8 \text { Gy fractions }\end{array}$ & $\begin{array}{l}5 / 8 \text { no disease } \\
\text { progression in } \\
10.5 \text { to } 50 \mathrm{mo}\end{array}$ & $\begin{array}{c}3 \mathrm{G} 1 \text { or } \mathrm{G} 2,1 \mathrm{G} 1 \\
\text { lower back pain }\end{array}$ \\
\hline Paly JJ et al. (29) & 2014 & 98 & Intraoperative & Retrospective & $9.5-20 \mathrm{~Gy}$ & $\begin{array}{c}5 \text {-year } \\
\text { for advanced disease: } \\
\text { OS=37\%, DSS }=41 \%, \\
\text { DFS }=39 \% \\
\text { for locally recurrent } \\
\text { disease: } \mathrm{OS}=55 \%, \\
\text { DSS=60\%, DFS }=52 \% .\end{array}$ & $\begin{array}{l}29 \% \text { perioperative } \\
\text { complication } \\
\text { rate }(\mathrm{G} 3-4)\end{array}$ \\
\hline Habl G et al. (30) & 2013 & 17 & $\begin{array}{c}\text { IOERT } \\
(17) \text { and } \\
\text { postoperative } \\
\text { EBRT (11) }\end{array}$ & Retrospective & $\begin{array}{c}\text { Median IOERT= } \\
15 \mathrm{~Gy}, \text { median } \\
\text { EBRT }=40 \mathrm{~Gy}\end{array}$ & $\begin{array}{c}\text { LCR: } 1-\mathrm{y}=91 \%, \\
2-\mathrm{y}=91 \% . \\
\text { OS: } 1-\mathrm{y}=81 \%, \\
2-\mathrm{y}=73 \% . \text { PFS: } \\
1-\mathrm{y}=49 \%, 2-\mathrm{y}=32 \%\end{array}$ & $\begin{array}{l}\text { Perioperative toxicity } \\
\text { in } 4 / 17 \text { (wound } \\
\text { healing disturbance, } \\
\text { intraabdominal } \\
\text { abscesses, acute renal } \\
\text { failure and } \\
\text { hyperglycemia) }\end{array}$ \\
\hline Calvo FA et al. (31) & 2013 & 25 & $\begin{array}{l}\text { IOERT }(25), \\
\text { preoperative } \\
\text { EBRT (3), } \\
\text { postoperative } \\
\text { EBRT (12) }\end{array}$ & Retrospective & $\begin{array}{c}\text { Median IOERT= } \\
14 \mathrm{~Gy}, \text { median } \\
\text { EBRT=44 Gy }\end{array}$ & $\begin{array}{l}\text { LCR } 5-\mathrm{y}=80 \%, \\
\text { distant metastases- } \\
\text { free survival } \\
\text { rate }=22 \%\end{array}$ & $6 / 25$ with $\geq \mathrm{G} 3$ \\
\hline Hallemeier et al. (32) & 2012 & 22 & $\begin{array}{l}\text { Perioperative } \\
\text { EBRT, } \\
\text { intraoperative } \\
\text { IOERT }\end{array}$ & Retrospective & $\begin{array}{l}\text { Median EBRT= } \\
45 \mathrm{~Gy}, \text { median } \\
\text { IOERT=12.5 Gy }\end{array}$ & $\begin{array}{c}1-\mathrm{y}: \text { OS }=91 \%, \\
\text { DFS }=64 \% \\
5 \text {-y: } \mathrm{OS}=40 \%, \\
\text { DFS }=31 \% \\
10-\mathrm{y}: \text { OS }=35 \%, \\
\text { DFS }=31 \%\end{array}$ & $\begin{array}{c}5 / 22 \mathrm{G} 3-5 \\
\text { postoperative } \\
\text { ARDS, pancreatic } \\
\text { pseudocyst, } \\
\text { perforated } \\
\text { duodenal ulcer }\end{array}$ \\
\hline Kjaer et al. (34) & 1987 & 65 & Postoperative & Prospective & $\begin{array}{l}\text { Total } 50 \text { Gy } \\
(2.5 \text { Gy in } \\
20 \text { fractions })\end{array}$ & $\begin{array}{l}\text { No difference in } \\
\text { relapse or } \\
\text { survival. } \\
\text { High fatal } \\
\text { complication rate }\end{array}$ & $\begin{array}{c}\text { Biochemical changes } \\
\text { in liver. } \\
\text { Bleeding and } \\
\text { stenosis in duodenum/ } \\
\text { small bowel. }\end{array}$ \\
\hline Stein et al. (35) & 1992 & $\begin{array}{c}56 \\
\text { irradiated } \\
147 \text { total }\end{array}$ & Postoperative & Retrospective & $\begin{array}{l}\text { Median total } \\
46 \text { Gy }(1.8- \\
2.0 \text { Gy daily) }\end{array}$ & $\begin{array}{l}\text { Actuarial survival. } \\
\text { 5-y:50\% in } \\
\text { irradiated, } 40 \% \text { non-. } \\
\quad 10-\mathrm{yr} 44 \% \text { in } \\
\text { irradiated, } 32 \% \text { non-. } \\
\text { Best local recurrence } \\
\text { rate for T3 N0M0 }\end{array}$ & $\begin{array}{c}5 \%(3 / 56) \\
\text { significant } \\
\text { toxicity } \\
\text { (small-bowel } \\
\text { obstruction) }\end{array}$ \\
\hline Tunio et al. (36) & 2010 & 735 & Postoperative & Meta-analysis & $\begin{array}{c}\text { Mean dose } \\
48.22 \text { Gy } \\
(24 \text { Gy }-63 \text { Gy) }\end{array}$ & $\begin{array}{l}\text { Significant reduction } \\
\text { of LRF }(p=0.0001) \text {. } \\
\text { No difference in } \\
\text { OS }(p=0.29) \text { and } \\
\text { DFS }(p=0.14) .\end{array}$ & $\begin{array}{l}\text { 6/735 treatment- } \\
\text { related deaths: } \\
\text { severe GI toxicity } \\
\text { (4) and hepatic } \\
\text { failure (2). }\end{array}$ \\
\hline
\end{tabular}

OS: Overall survival; DSS: disease-specific survival; DFS: disease-free survival; IOERT: intraoperative electron radiotherapy; EBRT: external beam radiotherapy; LCR: local control rate; PFS: progression-free survival; SF-SSRS: Single fraction spinal stereotactic radiosurgery; ARDS: adult respiratory distress syndrome; LRF: locoregional failure; mo: months; y: year. 
SBRT is an alternative non-invasive highly conformal RT technique which evolved from stereotactic radiosurgery for treating brain tumors. SBRT allows high doses per fraction to be delivered; it can target the metastatic lesion with high image-guided precision and at the same time protect the surrounding normal tissues, thereby minimizing the appearance of side effects. Furthermore, it is delivered in a small number of total fractions, typically five or less. The aim of SBRT is to overcome the RCC radioresistance that is usually seen when using the conventional fractionation for palliation.

It is estimated that brain metastases occur in almost $10 \%$ of RCC patients, are often hemorrhagic in nature and are associated with significant morbidity and mortality (38). More specifically, the median survival of patients with untreated brain metastases is approximately 1 to 2 months (47), while the median survival of patients treated with RT and corticosteroids is reported to be 2 to 8 months (48). Surgical resection should be considered for solitary lesions. However, since surgery is not always the best treatment option for all patients, WBRT can be an alternative therapeutic choice. Yet, although WBRT plays an important role for these patients, outcomes referring OS and LC are rather disappointing due to the known relative radioresistance of conventionally fractionated (49) RCC. On this basis, stereotactic radiosurgery (SRS), a method of EBRT, can deliver high RT doses with high precision and accuracy in a well-defined target volume, in one single or few RT fractions.

Local treatment strategies like surgical resection and stereotactic RT have shown favorable outcomes in selected patients $(47,50)$. In a retrospective study by Hernandez et al. (51) including 29 patients with 92 brain metastases from RCC, gamma knife radiosurgery (GKS) was performed. Fourteen patients also underwent WBRT before GKS and 2 patients after GKS. The mean dose of GKS delivered to the $50 \%$ isodose line at the tumor margin was $16.8 \mathrm{~Gy}$ (range=13-30 Gy). The overall median survival after GKS treatment was 7 months. The study concluded that the combination of WBRT with GKS could improve survival of RCC patients with brain metastases.

In 1990, Shibui et al. (52) reported that the median survival from diagnosis of brain metastases was 17 months for patients who underwent surgical resection compared to 4 months for patients who did not have surgery. The median survival for patients who underwent postoperative RT was 20 months, compared to 10.5 months for patients who underwent RT alone.

Another retrospective study by Ippen et al. evaluated the role of SRS in RCC patients and brain metastases (53). The study included 66 patients with 207 brain lesions treated with the Cyberknife (Accuray Inc., Sunnyvale, CA, USA) robotic frameless radiosurgery system. The follow-up period was 1 month and every 2-3 months after treatment. This period ended with the last scheduled follow-up or with the death of the patient. Follow-up included clinical examination and neuroimaging with contrast enhanced magnetic resonance imaging (MRI). Parameters that were assessed after SRS were OS, LC, distant-brain control, local progression-free survival and distant brain progression-free survival. All patients (a total of 207 lesions) were treated with SRS with the median prescription dose being 22 Gy. Twenty-four patients underwent surgical resection before SRS, 36 patients were treated with SRS only, and 6 patients had undergone prior WBRT with a median dose of 30Gy. Six patients underwent salvage WBRT after SRS and two patients were treated surgically due to disease progression after SRS.

The OS was 13.9, 21.9, and 5.9 months for patients treated with SRS only, additional surgery, and WBRT, respectively. The study concluded that SRS is a safe and effective treatment modality for RCC patients with brain metastases.

In a retrospective study by Wardak et al. (54), the role of SRS in the treatment of patients with RCC and brain metastases was evaluated. The study included 38 patients, with 1 to 26 brain metastases (median 2) treated per SRS session. The size of treated metastases ranged from 0.2 to $3.1 \mathrm{~cm}$ (median 0.6) and the dose ranged from 12 to 24 Gy (median 18). The OS after diagnosis of brain metastases was 13.8 months (median). The LC rate of all treated brain lesions was $91.8 \%$ at 1 year and $86.1 \%$ at 2 years. An interesting finding was that this control rate was inversely associated with lesion size and metastatic volume. It was concluded that brain metastases can be effectively controlled with SRS. Furthermore, another retrospective study by Moraes et al. (55) concluded that the incidence of local failure was strongly correlated to the metastatic lesion size and the prescribed dose, following SRS for brain metastases from RCC.

Palliative RT represents an effective treatment modality for patients with symptomatic bone metastases since it can relieve pain and control neurologic symptoms. Conventional RT has traditionally been a valuable treatment modality for patients with bone metastases. It is used as a primary treatment for symptomatic osseous sites, as an adjuvant treatment after surgical decompression for spinal cord compression, or therapeutic or prophylactic internal fixation of the affected bone $(56,57)$. However, highly conformal RT techniques such as three-dimensional conformal RT (3DCRT), intensity modulated RT (IMRT) and SBRT are promising in terms of treating bone metastases especially in critical sites such as the spine (58). Many prospective studies have shown effective results regarding LC after delivering palliative RT to painful bone metastases by using both SBRT and 3DCRT $(59,60)$.

Ghia et al. (61) conducted a study where spinal SRS was delivered in $43 \mathrm{RCC}$ patients with a total of 47 spinal metastatic sites. Patients enrolled in 2 different prospective protocols and were treated with SRS. A secondary analysis 
Table II. Metastatic RCC studies included in this review.

\begin{tabular}{|c|c|c|c|c|c|c|c|}
\hline Author & Year & Patients & $\begin{array}{c}\text { Metastatic } \\
\text { lesions treated }\end{array}$ & $\begin{array}{l}\text { Most common } \\
\text { metastatic site }\end{array}$ & Treatment groups & Dose & Outcome \\
\hline Ippen et al. (53) & 2015 & 66 & 207 & Brain only & $\begin{array}{c}\text { SRS, surgery+SRS, } \\
\text { WBRT+SRS }\end{array}$ & $\begin{array}{l}\text { Median } \\
\text { prescription } \\
22 \mathrm{~Gy}\end{array}$ & $\begin{array}{c}\text { SRS: OS }=13.9 \mathrm{mo}, \\
\text { LCR }=84 \% . \\
\text { Surgery }+ \text { SRS: } \\
\text { OS=21.9 mo, LCR }=94 \% . \\
\text { WBRT }+ \text { SRS: } \\
\text { OS }=5.9 \text { mo, } \text { LCR }=88 \% .\end{array}$ \\
\hline Wardak et al. (54) & 2019 & 38 & 243 & Brain only & SRS & Median 18 Gy & $\begin{array}{c}\operatorname{LCR}(1-\mathrm{y})=91.8 \% \\
\operatorname{LCR}(2-\mathrm{y})=86.1 \% \\
1-\mathrm{y} \text { survival }=57.5 \%\end{array}$ \\
\hline Ghia et al. (61) & 2016 & 43 & 47 & Spine only & $\begin{array}{l}\text { SF-SSRS (21), } \\
\text { MF-SSRS (26) }\end{array}$ & $\begin{array}{c}\text { SF: } 24 \text { Gy } \\
\text { MF: } 27 \text { Gy in } \\
3 \text { fractions }(20) \text { or } \\
30 \text { Gy in } 5 \\
\text { fractions (6) }\end{array}$ & $\begin{array}{c}\text { SF: } 1-y \text { act } \\
\text { LCR }=95 \%, \\
2-y \text { act } \mathrm{LCR}=86 \% . \\
\text { MF: } 1-\mathrm{y} \text { act } \mathrm{LCR}=71 \%, \\
2-\mathrm{y} \text { act } \mathrm{LCR}=55 \% .\end{array}$ \\
\hline Lee et al. (60) & 2005 & 31 & 31 & Bone $(25 / 31)$ & Palliative RT & $\begin{array}{l}30 \text { Gy in } \\
10 \text { fractions }\end{array}$ & $\begin{array}{l}83 \% \text { site-specific pain } \\
\text { relief, } 48 \% \text { no increase } \\
\text { in analgesic medication, } \\
\text { 33\% global pain response } \\
\text { improvement, 33\% global } \\
\text { QOL improvement }\end{array}$ \\
\hline
\end{tabular}

SRS: Stereotactic radiosurgery; WBRT: whole brain radiation therapy; OS: overall survival; mo: months; y: year; LCR: local control rate; SF: single fraction; MF: multi fraction; SSRS: spinal stereotactic radiosurgery; QOL: quality of life.

was performed in patients with previously non irradiated RCC spinal metastases treated with either single-fraction (SF) or multi-fraction (MF) SRS. Fifteen metastatic sites underwent surgical intervention prior to SRS that included laminectomy. All patients who underwent SF-SRS received a total dose of $24 \mathrm{~Gy}$ while patients who underwent MF regiments received either 27 Gy in 3 fractions or 30 Gy in 5 fractions. The estimated median OS for the entire cohort was 22.8 months while the median LC was 80.6 months with 1year and 2-year actuarial LC rates of $82 \%$ and $68 \%$, respectively. SF SRS was related to improved 1- and 2-year actuarial LC relative to MF-SRS (95\% vs. $71 \%$ and $86 \%$ vs. $55 \%$, respectively). The study concluded that SRS is an effective treatment option regarding LC for RCC with spinal metastases. SF-SRS is associated with a better LC compared to MF-SRS for previously non-irradiated RCC patients with spinal metastases.

Lee et al. (60) delivered palliative RT of a total dose of 30 Gy in 10 fractions in symptomatic metastatic RCC with bone metastases and found a significant response rate regarding the relief of local symptoms. The RT technique, the energy that was used and the prescription point were determined by the radiation physicist. Patient evaluation was performed before RT, 1 month and 3 months after RT, and every 3 months to 1 year thereafter.

Wardak et al. (62) evaluated the pain response and prevention of vertebral compression fractures following vertebroplasty after SABR, in a phase II clinical trial. The study included 23 patients that underwent single fraction spine SABR, followed by prophylactic vertebroplasty. It was established that the pain response was improved compared with conventional radiation therapy, providing also long-term pain control and better structural stability of the spine. Furthermore, concurrent application of bisphosphonates and RT in RCC patients with bone metastases has been reported to provide both clinical and radiological response through synergistic action (63).

The above studies are summarized in Table II.

\section{Management of Oligometastatic Disease}

Oligometastatic disease, i.e. limited metastatic disease, was first described in 1995 by Hellman and Weichselbaum (64). Oligometastatic RCC is referring to a limited metastatic disease state in which cancer is not characterized by widespread dissemination (64). Metastases are present in limited anatomic locations, typically between 1 and 5 metastatic lesions, with patients at this state achieving better outcomes regarding survival when treated by locally directed therapies.

The exact determination of which oligometastatic RCC patients are the best candidates for treatment still remains unclear. However, Dagan et al. (65) suggests that most radiation oncologists strongly believe that oligometastatic 
therapy should be delivered to patients with good performance status, having up to 5 metastatic lesions, where all lesions can be treated in order to obtain LC in all sites. Patients of this state should be treated aggressively in order to achieve better survival.

Evolving RT techniques such as SBRT may play an important role in treating patients with oligometastases. Due to lack of clinical evidence in the past decade, it was rather unclear which were the best indications for SBRT and which patients were the best candidates.

Franzese et al. (66) conducted a retrospective study evaluating the role of SBRT for oligometastatic RCC. The study included 58 RCC patients presenting with limited metastatic disease (73 lesions) of a maximum of 3 metastases. Totally, $53.4 \%$ were located in the lungs, $26 \%$ in the lymph nodes, $9.5 \%$ in the bones, $4.1 \%$ in the liver and $6.8 \%$ in the adrenal gland. Patients were originally treated by surgical excision of their primary tumor, however, surgical excision of the metastatic lesion was not feasible. The dose delivered ranged from 18 to 75 Gy over 1 to 10 fractions. The LC rate at 12 and 18 months was $90.2 \%$ and $90.2 \%$, respectively. The progression-free survival rate at 12 and 18 months was $46.2 \%$ and $35 \%$, respectively. The study concluded that SBRT was effective regarding oligometastatic RCC with acceptable toxicity.

Other studies have also mentioned the effective role of SBRT for oligometastatic disease, regarding LC and palliation of metastatic symptoms when compared to conventionally fractionated RT $(67,68)$. In a retrospective study of 188 patients by Meyer et al. (69), it was concluded that Stereotactic Radiation therapy (SRT) was an effective and safe in treating patients with oligometastatic and oligoprogressive RCC. In another retrospective study of 48 metastatic RCC patients receiving extra-cranial SBRT, Buti et al. (70) concluded that SBRT was effective as well as safe, in improving LC and delaying systemic treatment.

However, although SBRT is a promising treatment option for oligometastatic renal cancer, several issues remain unclear and thus more studies are needed to best evaluate its benefit. More clinical trials are needed regarding a) the optimal RT dose required to achieve maximum LC rate and improve OS, and b) identification of the ideal oligometastatic RCC candidates who will undergo RT.

\section{Combination of Radiotherapy With Immune Checkpoint Inhibitors (ICIs)}

Recent successful incorporation of ICIs in the treatment of RCC has brought up the issue of combination of RT with these agents and whether it may maximize the clinical benefit. The rationale for this combination is based on the ability of RT to augment the immunogenicity of tumors, which can increase the potential for synergistic interplay and eventually for tumor response (71). Using a mouse model, Deng et al. showed that 12 Gy in a single fraction can induce synergistic effects in combination with anti-PDL-1 inhibitors (72). A potential synergy between RT and ICIs has also been reported by Kroon et al. in a pre-clinical melanoma model (73). Additionally, it has been documented that large RT doses (12-18 Gy) can induce the Three-prime repair exonuclease 1 (Trex1), a DNA exonuclease, leading to degradation and cytosolic accumulation of DNA, which in turn increases the secretion of type-I interferons by cancer cells. On the contrary, lower and repeated doses that do not induce Trex 1, stimulate the production of Interferon-beta (IFN $\beta$ ) which is crucial for the recruitment and activation of dendritic cells (DCs). The latter orchestrate the priming of cytotoxic CD8+ T cells, which lead to complete tumor regression in the presence of ICIs (74). It seems that RT exerts a context- and dose-dependent effect on the tumor immune compartment, which may determine the clinical efficacy of ICI co-administration in the context of a combination strategy with RT (75).

Unfortunately, until now, a very limited number of studies have been published having evaluated the clinical utility of the concomitant strategy in the treatment of RCC, while more studies are ongoing. A few years ago, Alexander et al. published the case of a metastatic clear cell RCC (ccRCC) patient who harbored a chest wall metastatic lesion. This patient received, during a clinical trial, palliative RT on chest wall combined with pembrolizumab presenting eventually a rapid disease progression. However, no convincing etiological association was provided for this detrimental clinical course (76). Very recently, preliminary results from the NIVES study, which is a phase II clinical trial assessing the combination of nivolumab with SBRT in metastatic RCC, showed that the objective response rate (ORR) was $17.4 \%$, which did not reach the primary endpoint of improving ORR to $40 \%$ (77). In addition, in the RADVAX single-center trial, which studied dual checkpoint inhibitors (nivolumab/ipilimumab) in combination with SBRT in advanced ccRCC patients, the ORR was 56\% (higher than the expected ORR of $\sim 40 \%$ ). However, the small number of enrolled patients $(n=25)$ was the major limitation of this study, reducing the clinical significance of the published results (78).

\section{Combination of Radiotherapy With Targeted Agents}

Tyrosine kinase inhibitors (TKIs) remain a therapeutic pillar on advanced RCC management. The integration of RT in the treatment template is a reasonable option, taking into account that TKIs not only mediate the inhibition of angiogenesis, but also have a close interaction with the immune system, leading to immunity reprogramming (79). 
Staehler et al. documented that anti-angiogenic TKIs (sunitinib or sorafenib) combined with stereotactic RT in patients with central nervous system (CNS) metastatic RCC disease was a safe strategy and control of symptoms was excellent (80). In addition, clinical utility of this combination has also been confirmed in a multi-institutional phase II trial, where sunitinib was administered in conjunction with hypofractionated RT (10 fractions, $50 \mathrm{~Gy}$ ) in 25 patients (4 of them having RCC) with oligometastatic disease. The combinational treatment led to a significant clinical response (81). Besides, RCC patients experienced a longer survival benefit with 4-year OS reaching $83 \%$ (82). Supportive results also came from two retrospective trials. Kusuda et al. reported that the combination of sunitinib with RT in five RCC patients with brain metastases was safe and efficacious (83). In a bigger study, in which $100 \mathrm{mRCC}$ patients were treated in a first-line setting with stereotactic spinal RT accompanied or not from TKIs, the combination group had a favorable prognosis and an improved LC (84). Recently, He et al. confirmed the previous results in a cohort of 56 patients, treated with TKIs combined with SBRT; the addition of SBRT to TKIs increased the survival benefit and patients being irradiated prior to TKI resistance presented higher complete response rates (85). Despite the promising initial results, more multi-institutional studies with adequate number of patients are necessary in order to prove the clinical efficacy of the combination strategy.

\section{Conclusion}

RCC has been traditionally considered a radioresistant malignancy. However, modern high precision RT techniques, such as IMRT and SBRT, aim to overcome this theory and provide us with a challenging therapeutic option for RCC patients. This will be accomplished by adopting modern RT methods and procedures such as delivering higher doses per fraction that can overcome the RCC radioresistance. This RT "renaissance" (86) can potentially achieve optimal therapeutic outcomes regarding loco-regional control of advanced disease and symptom alleviation due to metastatic RCC disease. However, further studies are required to enable us to define the benefits and the control rates of RT treatment on RCC patients by the use of novel RT techniques.

\section{Conflicts of Interest}

None to be declared.

\section{Authors' Contributions}

DS conceived the presented idea, designed and drafted the manuscript, revised and approved the final version. PT worked out the technical details, organized the research, analysis and presentation of the data and revised the final version. F-I D and MT contributed substantially to the original manuscript. AK provided critical feedback for the manuscript. DV, ML, NP, AG and HK contributed to the final version of the manuscript. DK was in charge of overall direction and planning of the manuscript. All Authors read and approved the final manuscript.

\section{References}

1 Hepgur M, Sadeghi S, Dorff TB and Quinn DI: Tivozanib in the treatment of renal cell carcinoma. Biologics 7: 139-148, 2013. PMID: 23788831. DOI: 10.2147/BTT.S32958

2 Chow WH and Devesa SS: Contemporary epidemiology of renal cell cancer. Cancer J 14(5): 288-301, 2008. PMID: 18836333. DOI: $10.1097 / \mathrm{PPO} .0 \mathrm{~b} 013 \mathrm{e} 3181867628$

3 Qayyum T, Oades G, Horgan P, Aitchison M and Edwards J: The epidemiology and risk factors for renal cancer. Curr Urol 6(4): 169-174, 2013. PMID: 24917738. DOI: 10.1159/000343534

4 Hsieh J, Purdue M, Signoretti S, Swanton C, Albiges L, Schmidinger M, Heng D, Larkin J and Ficarra V: Renal cell carcinoma. Nat Rev Dis Primer 3(1): 1-19, 2017. DOI: $10.1038 /$ nrdp .2017 .9

5 O'Toole KM, Brown M and Hoffmann P: Pathology of benign and malignant kidney tumors. Urol Clin North Am 20(2): 193205, 1993. PMID: 8388134.

6 Zisman A, Pantuck AJ, Wieder J, Chao DH, Dorey F, Said JW, deKernion JB, Figlin RA and Belldegrun AS: Risk group assessment and clinical outcome algorithm to predict the natural history of patients with surgically resected renal cell carcinoma. J Clin Oncol 20(23): 4559-4566, 2002. PMID: 12454113. DOI: 10.1200/JCO.2002.05.111

7 Chen DY and Uzzo RG: Evaluation and management of the renal mass. Med Clin North Am 95(1): 179-189, 2011. PMID: 21095421. DOI: 10.1016/j.mcna.2010.08.021

8 Blanco AI, Teh BS and Amato RJ: Role of radiation therapy in the management of renal cell cancer. Cancers (Basel) 3(4): 40104023, 2011. PMID: 24213122. DOI: 10.3390/cancers3044010

9 Deschavanne PJ and Fertil B: A review of human cell radiosensitivity in vitro. Int J Radiat Oncol Biol Phys 34(1): 251266, 1996. PMID: 12118559. DOI: 10.1016/0360-3016(95) 02029-2

10 Kim SP, Murad MH, Thompson RH, Boorjian SA, Weight CJ, Han LC, Erwin PJ, Costello BA, Chow GK and Leibovich BC: Comparative effectiveness for survival and renal function of partial and radical nephrectomy for localized renal tumors: A systematic review and meta-analysis. J Urol: 2012. PMID: 23085064. DOI: 10.1016/j.juro.2012.10.026

11 Cindolo L, Chiodini P, Gallo C, Ficarra V, Schips L, Tostain J, de La Taille A, Artibani W and Patard JJ: Validation by calibration of the UCLA integrated staging system prognostic model for nonmetastatic renal cell carcinoma after nephrectomy. Cancer 113(1): 65-71, 2008. PMID: 18473356. DOI: 10.1002/ cncr.23517

12 Zequi SC: Editorial comment: The emerging role of stereotactic ablative radiotherapy for primary renal cell carcinoma: A systematic review and meta-analysis. Int Braz J Urol 46(3): 473, 2020. PMID: 32167721. DOI: 10.1590/S1677-5538.IBJU. 2020.03.10

13 Escudier B, Eisen T, Porta C, Patard J, Khoo V, Algaba F, Mulders P and Kataja V: Renal cell carcinoma: ESMO clinical practice guidelines for diagnosis, treatment and follow-up. 
Annals of Oncology 23: vii65-vii71, 2020. DOI: 10.1093/ annonc/mds227

14 Motzer R, Jonasch E, Agarwal N, Bhayani S, Bro W, Chang S, Choueiri T, Costello B, Derweesh I, Fishman M, Gallagher T, Gore J, Hancock S, Harrison M, Kim W, Kyriakopoulos C, Lagrange C, Lam E, Lau C, Michaelson M, Olencki T, Pierorazio P, Plimack E, Redman B, Shuch B, Somer B, Sonpavde G, Sosman J, Dwyer M and Kumar R: Kidney cancer, version 2.2017, NCCN clinical practice guidelines in oncology. Journal of the National Comprehensive Cancer Network 15(6): 804-834, 2019. DOI: 10.6004/jnccn. 2017.0100

15 Choueiri TK and Motzer RJ: Systemic therapy for metastatic renal-cell carcinoma. N Engl J Med 376(4): 354-366, 2017. PMID: 28121507. DOI: 10.1056/NEJMra1601333

16 Zerdes I, Tolia M, Tsoukalas N, Mitsis M, Kardamakis D, Pistevou-Gombaki K, Tsekeris P and Kyrgias G: Systemic therapy of metastatic renal cell carcinoma: Review of the current literature. Urologia 86(1): 3-8, 2019. PMID: 30270773. DOI: $10.1177 / 0391560318802166$

17 Yamamoto T, Kadoya N, Takeda K, Matsushita H, Umezawa R, Sato K, Kubozono M, Ito K, Ishikawa Y, Kozumi M, Takahashi N, Katagiri Y, Onishi H and Jingu K: Renal atrophy after stereotactic body radiotherapy for renal cell carcinoma. Radiat Oncol 11: 72, 2016. PMID: 27229710. DOI: 10.1186/s13014016-0651-5

18 Garcia-Barros M, Paris F, Cordon-Cardo C, Lyden D, Rafii S, Haimovitz-Friedman A, Fuks Z and Kolesnick R: Tumor response to radiotherapy regulated by endothelial cell apoptosis. Science 300(5622): 1155-1159, 2003. PMID: 12750523. DOI: 10.1126/science. 1082504

19 Ning S, Trisler K, Wessels BW and Knox SJ: Radiobiologic studies of radioimmunotherapy and external beam radiotherapy in vitro and in vivo in human renal cell carcinoma xenografts. Cancer 80(12 Suppl): 2519-2528, 1997. PMID: 9406705. DOI: 10.1002/(sici)1097-0142(19971215)80:12+<2519::aidcncr26>3.3.co; $2-\mathrm{t}$

20 Otto U, Huland H, Baisch H and Klöppel G: Transplantation of human renal cell carcinoma into NMRI nu/nu mice. III. Effect of irradiation on tumor acceptance and tumor growth. J Urol 134(1): 170-174, 1985. PMID: 4009817. DOI: 10.1016/s00225347(17)47050-9

21 Funayama S, Onishi H, Kuriyama K, Komiyama T, Marino K, Araya M, Saito R, Aoki S, Maehata Y, Nonaka H, Tominaga L, Muramatsu J, Nakagomi H, Kamiyama M and Takeda M: Renal cancer is not radioresistant: Slowly but continuing shrinkage of the tumor after stereotactic body radiation therapy. Technol Cancer Res Treat 18: 1533033818822329, 2019. PMID: 30803362. DOI: $10.1177 / 1533033818822329$

22 De Meerleer G, Khoo V, Escudier B, Joniau S, Bossi A, Ost P, Briganti A, Fonteyne V, Van Vulpen M, Lumen N, Spahn M and Mareel M: Radiotherapy for renal-cell carcinoma. Lancet Oncol 15(4): e170-e177, 2014. PMID: 24694640. DOI: 10.1016/S14702045(13)70569-2

23 Correa RJM, Rodrigues GB, Chen H, Warner A, Ahmad B and Louie AV: Stereotactic ablative radiotherapy (SABR) for large renal tumors: A retrospective case series evaluating clinical outcomes, toxicity, and technical considerations. Am J Clin Oncol 41(6): 568-575, 2018. PMID: 27635623. DOI: 10.1097/ COC.0000000000000329
24 Siva S, Chesson B, Bressel M, Pryor D, Higgs B, Reynolds HM, Hardcastle N, Montgomery R, Vanneste B, Khoo V, Ruben J, Lau E, Hofman MS, De Abreu Lourenco R, Sridharan S, Brook NR, Martin J, Lawrentschuk N, Kron T and Foroudi F: TROG 15.03 phase II clinical trial of focal ablative stereotactic radiosurgery for cancers of the kidney - Fastrack II. BMC Cancer 18(1): 1030, 2018. PMID: 30352550. DOI: 10.1186/s12885-018-4916-2

25 Grubb WR, Ponsky L, Lo SS, Kharouta M, Traughber B, Sandstrom K, MacLennan GT, Shankar E, Gupta S, Machtay M and Ellis RJ: Final results of a dose escalation protocol of stereotactic body radiotherapy for poor surgical candidates with localized renal cell carcinoma. Radiother Oncol 155: 138-143, 2021. PMID: 33214131. DOI: 10.1016/j.radonc.2020.10.031

26 Juusela H, Malmio K, Alfthan O and Oravisto KJ: Preoperative irradiation in the treatment of renal adenocarcinoma. Scand $\mathrm{J}$ Urol Nephrol 11(3): 277-281, 1977. PMID: 594674. DOI: $10.3109 / 00365597709179965$

27 Van der werf-messing B: Carcinoma of the kidney. Cancer 32(5): 1056-1061， 2020. DOI: 10.1002/1097-0142(197311)32:5< 1056::AID-CNCR2820320505>3.0.CO;2-M

28 Frydenberg M, Gunderson L, Hahn G, Fieck J and Zincke H: Preoperative external beam radiotherapy followed by cytoreductive surgery and intraoperative radiotherapy for locally advanced primary or recurrent renal malignancies. J Urol 152(1): 15-21, 1994. PMID: 8201647. DOI: 10.1016/s0022-5347(17) 32805-7

29 Paly JJ, Hallemeier CL, Biggs PJ, Niemierko A, Roeder F, Martínez-Monge R, Whitson J, Calvo FA, Fastner G, Sedlmayer F, Wong WW, Ellis RJ, Haddock MG, Choo R, Shipley WU, Zietman AL and Efstathiou JA: Outcomes in a multi-institutional cohort of patients treated with intraoperative radiation therapy for advanced or recurrent renal cell carcinoma. Int J Radiat Oncol Biol Phys 88(3): 618-623, 2014. PMID: 24411190. DOI: 10.1016/j.ijrobp.2013.11.207

30 Habl G, Uhl M, Hensley F, Pahernik S, Debus J and Röder F: Intraoperative electron radiation therapy (IOERT) in patients with locally recurrent renal cell carcinoma. Radiat Oncol 8: 282, 2013. PMID: 24295293. DOI: 10.1186/1748-717X-8-282

31 Calvo FA, Sole CV, Martinez-Monge R, Azinovic I, Aristu J, Zudaire J, Garcia-Sabrido JL and Berian JM: Intraoperative EBRT and resection for renal cell carcinoma : Twenty-year outcomes. Strahlenther Onkol 189(2): 129-136, 2013. PMID: 23223810. DOI: $10.1007 / \mathrm{s} 00066-012-0272-3$

32 Hallemeier CL, Choo R, Davis BJ, Pisansky TM, Gunderson LL, Leibovich BC and Haddock MG: Long-term outcomes after maximal surgical resection and intraoperative electron radiotherapy for locoregionally recurrent or locoregionally advanced primary renal cell carcinoma. Int J Radiat Oncol Biol Phys 82(5): 1938-1943, 2012. PMID: 21514065. DOI: 10.1016/j.ijrobp.2011.02.026

33 Kjaer M, Iversen P, Hvidt V, Bruun E, Skaarup P, Bech Hansen $\mathrm{J}$ and Frederiksen PL: A randomized trial of postoperative radiotherapy versus observation in stage II and III renal adenocarcinoma. A study by the Copenhagen Renal Cancer Study Group. Scand J Urol Nephrol 21(4): 285-289, 1987. PMID: 3445125. DOI: 10.3109/00365598709180784

34 Kjaer M, Frederiksen PL and Engelholm SA: Postoperative radiotherapy in stage II and III renal adenocarcinoma. A randomized trial by the Copenhagen renal cancer study group. 
Int J Radiat Oncol Biol Phys 13(5): 665-672, 1987. PMID: 3553111. DOI: 10.1016/0360-3016(87)90283-5

35 Stein M, Kuten A, Halpern J, Coachman NM, Cohen Y and Robinson E: The value of postoperative irradiation in renal cell cancer. Radiother Oncol 24(1): 41-44, 1992. PMID: 1620886. DOI: 10.1016/0167-8140(92)90352-u

36 Tunio MA, Hashmi A and Rafi M: Need for a new trial to evaluate postoperative radiotherapy in renal cell carcinoma: A meta-analysis of randomized controlled trials. Ann Oncol 21(9): 1839-1845, 2010. PMID: 20139152. DOI: 10.1093/annonc/ mdq028

37 Flanigan RC, Campbell SC, Clark JI and Picken MM: Metastatic renal cell carcinoma. Curr Treat Options Oncol 4(5): 385-390, 2003. PMID: 12941198. DOI: 10.1007/s11864-003-0039-2

38 Heinzer $\mathrm{H}$, Huland $\mathrm{E}$ and Huland $\mathrm{H}$ : Behandlung des metastasierten Nierenzellkarzinoms. Der Urologe A 39(4): 356361, 2019. DOI: $10.1007 / \mathrm{s} 001200050370$

39 Alt AL, Boorjian SA, Lohse CM, Costello BA, Leibovich BC and Blute ML: Survival after complete surgical resection of multiple metastases from renal cell carcinoma. Cancer 117(13): 2873-2882, 2011. PMID: 21692048. DOI: 10.1002/cncr.25836

40 Meyer CP, Sun M, Karam JA, Leow JJ, de Velasco G, Pal SK, Chang SL, Trinh QD and Choueiri TK: Complications after metastasectomy for renal cell carcinoma-A population-based assessment. Eur Urol 72(2): 171-174, 2017. PMID: 28359734. DOI: 10.1016/j.eururo.2017.03.005

41 Cannady SB, Cavanaugh KA, Lee SY, Bukowski RM, Olencki TE, Stevens GH, Barnett GH and Suh JH: Results of whole brain radiotherapy and recursive partitioning analysis in patients with brain metastases from renal cell carcinoma: A retrospective study. Int J Radiat Oncol Biol Phys 58(1): 253-258, 2004 PMID: 14697446. DOI: 10.1016/s0360-3016(03)00818-6

42 Culine S, Bekradda M, Kramar A, Rey A, Escudier B and Droz JP: Prognostic factors for survival in patients with brain metastases from renal cell carcinoma. Cancer 83(12): 25482553, 1998. PMID: 9874462.

43 Fokas E, Henzel M, Hamm K, Surber G, Kleinert G and Engenhart-Cabillic R: Radiotherapy for brain metastases from renal cell cancer: Should whole-brain radiotherapy be added to stereotactic radiosurgery? Analysis of 88 patients. Strahlenther Onkol 186(4): 210-217, 2010. PMID: 20165820. DOI: 10.1007/s00066-010-2055-z

44 Gay P, Litchyz W and Cascino T: Brain metastasis in hypernephroma. Journal of Neuro-Oncology 5(1): 51-56, 2019. DOI: $10.1007 / \mathrm{BF} 00162765$

45 Ikushima H, Tokuuye K, Sumi M, Kagami Y, Murayama S, Ikeda H, Tanaka M, Oyama H, Shibui $S$ and Nomura K: Fractionated stereotactic radiotherapy of brain metastases from renal cell carcinoma. Int J Radiat Oncol Biol Phys 48(5): 13891393, 2000. PMID: 11121638. DOI: 10.1016/s03603016(00)00804-x

46 Wrónski M, Maor MH, Davis BJ, Sawaya R and Levin VA: External radiation of brain metastases from renal carcinoma: A retrospective study of 119 patients from the M. D. Anderson Cancer Center. Int J Radiat Oncol Biol Phys 37(4): 753-759, 1997. PMID: 9128947. DOI: 10.1016/s0360-3016(97)00006-0

47 Sheehan JP, Sun MH, Kondziolka D, Flickinger J and Lunsford LD: Radiosurgery in patients with renal cell carcinoma metastasis to the brain: Long-term outcomes and prognostic factors influencing survival and local tumor control. J Neurosurg
98(2): 342-349, 2003. PMID: 12593621. DOI: 10.3171/ jns.2003.98.2.0342

48 Schöggl A, Kitz K, Ertl A, Dieckmann K, Saringer W and Koos WT: Gamma-knife radiosurgery for brain metastases of renal cell carcinoma: Results in 23 patients. Acta Neurochir (Wien) 140(6): 549-555, 1998. PMID: 9755321. DOI: 10.1007/s007010050139

49 Kim YH, Kim JW, Chung HT, Paek SH, Kim DG and Jung HW: Brain metastasis from renal cell carcinoma. Prog Neurol Surg 25: 163-175, 2012. PMID: 22236678. DOI: 10.1159/000331190

$50 \mathrm{Du}$ Y, Pahernik S, Hadaschik B, Teber D, Duensing S, Jäger D, Hohenfellner $M$ and Grüllich $C$ : Impact of resection and systemic therapy on the survival of patients with brain metastasis of metastatic renal cell carcinoma. J Neurooncol 130(1): 221228, 2016. PMID: 27538910. DOI: 10.1007/s11060-016-2238-2

51 Hernandez L, Zamorano L, Sloan A, Fontanesi J, Lo S, Levin K, Li Q and Diaz F: Gamma knife radiosurgery for renal cell carcinoma brain metastases. J Neurosurg 97(5 Suppl): 489-493, 2002. PMID: 12507083. DOI: 10.3171/jns.2002.97.supplement

52 Shibui S, Nishikawa R and Nomura K: [Treatment of metastatic brain tumor from renal cell carcinoma]. No Shinkei Geka 18(10): 935-938, 1990. PMID: 2234294.

53 Ippen FM, Mahadevan A, Wong ET, Uhlmann EJ, Sengupta S and Kasper EM: Stereotactic radiosurgery for renal cancer brain metastasis: Prognostic factors and the role of whole-brain radiation and surgical resection. J Oncol 2015: 636918, 2015. PMID: 26681942. DOI: 10.1155/2015/636918

54 Wardak Z, Christie A, Bowman A, Stojadinovic S, Nedzi L, Barnett S, Patel T, Mickey B, Whitworth T, Hannan R, Brugarolas J and Timmerman R: Stereotactic radiosurgery for multiple brain metastases from renal-cell carcinoma. Clin Genitourin Cancer 17(2): e273-e280, 2019. PMID: 30595522. DOI: $10.1016 /$ j.clgc.2018.11.006

55 Moraes FY, Winter J, Atenafu EG, Dasgupta A, Raziee H, Coolens C, Millar BA, Laperriere N, Patel M, Bernstein M, Kongkham P, Zadeh G, Conrad T, Chung C, Berlin A and Shultz DB: Outcomes following stereotactic radiosurgery for small to medium-sized brain metastases are exceptionally dependent upon tumor size and prescribed dose. Neuro Oncol 21(2): 242251, 2019. PMID: 30265328. DOI: 10.1093/neuonc/noy159

56 Wu JS, Wong R, Johnston M, Bezjak A, Whelan T and Cancer Care Ontario Practice Guidelines Initiative Supportive Care Group: Meta-analysis of dose-fractionation radiotherapy trials for the palliation of painful bone metastases. Int J Radiat Oncol Biol Phys 55(3): 594-605, 2003. PMID: 12573746. DOI: 10.1016/s0360-3016(02)04147-0

57 Hartsell WF, Scott CB, Bruner DW, Scarantino CW, Ivker RA, Roach M 3rd, Suh JH, Demas WF, Movsas B, Petersen IA, Konski AA, Cleeland CS, Janjan NA and DeSilvio M: Randomized trial of short- versus long-course radiotherapy for palliation of painful bone metastases. J Natl Cancer Inst 97(11): 798-804, 2005. PMID: 15928300. DOI: 10.1093/jnci/dji139

58 Lo SS, Sahgal A, Hartsell WF, Lutz ST, Kardamakis D, van der Linden Y and Hoskin PJ: The treatment of bone metastasis with highly conformal radiation therapy: A brave new world or a costly mistake? Clin Oncol (R Coll Radiol) 21(9): 662-664, 2009. PMID: 19744842. DOI: 10.1016/j.clon.2009.08.001

59 Janssen S, Dahlke M, Trang NT, Khoa MT and Rades D: Estimation of the six-month survival probability after radiosurgery for brain metastases from kidney cancer. Anticancer Res 35(7): 4215-4217, 2015. PMID: 26124381. 
60 Lee J, Hodgson D, Chow E, Bezjak A, Catton P, Tsuji D, O'Brien M, Danjoux C, Hayter C, Warde P and Gospodarowicz MK: A phase II trial of palliative radiotherapy for metastatic renal cell carcinoma. Cancer 104(9): 1894-1900, 2005. PMID: 16177996. DOI: $10.1002 /$ cncr.21410

61 Ghia AJ, Chang EL, Bishop AJ, Pan HY, Boehling NS, Amini B, Allen PK, Li J, Rhines LD, Tannir NM, Tatsui CE, Brown PD and Yang JN: Single-fraction versus multifraction spinal stereotactic radiosurgery for spinal metastases from renal cell carcinoma: Secondary analysis of Phase I/II trials. J Neurosurg Spine 24(5): 829-836, 2016. PMID: 26799117. DOI: 10.3171/2015.8.SPINE15844

62 Wardak Z, Bland R, Ahn C, Xie XJ, Chason D, Morrill K, Stehel E, Nedzi L, Ding C, Medin P, Boike T, Abdulrahman R, Folkert M, Iyengar P, Kim N, Choy H, Bagley C and Timmerman R: a phase 2 clinical trial of SABR followed by immediate vertebroplasty for spine metastases. Int J Radiat Oncol Biol Phys 104(1): 83-89, 2019. PMID: 30684664. DOI: 10.1016/j.ijrobp. 2019.01.072

63 Vassiliou V, Leotsinides M, Kalogeropoulou C and Kardamakis D: Concurrent application of bisphosphonates and external beam radiotherapy in patients with metastatic bone disease from renal cancer. BJU Int 104(3): 417-8; author reply 418, 2009. PMID: 19614659. DOI: 10.1111/j.1464-410X.2009.08767_3.x

64 Hellman S and Weichselbaum RR: Oligometastases. J Clin Oncol 13(1): 8-10, 1995. PMID: 7799047. DOI: 10.1200/ JCO.1995.13.1.8

65 Dagan R, Lo SS, Redmond KJ, Poon I, Foote MC, Lohr F, Ricardi U and Sahgal A: A multi-national report on stereotactic body radiotherapy for oligometastases: Patient selection and follow-up. Acta Oncol 55(5): 633-637, 2016. PMID: 27046290. DOI: 10.3109/0284186X.2015.1118659

66 Franzese C, Franceschini D, Di Brina L, D’Agostino GR, Navarria P, Comito T, Mancosu P, Tomatis S and Scorsetti M: Role of stereotactic body radiation therapy for the management of oligometastatic renal cell carcinoma. J Urol 201(1): 70-75, 2019. PMID: 30577391. DOI: 10.1016/j.juro.2018.08.049

67 Amini A, Altoos B, Bourlon MT, Bedrick E, Bhatia S, Kessler ER, Flaig TW, Fisher CM, Kavanagh BD, Lam ET and Karam SD: Local control rates of metastatic renal cell carcinoma (RCC) to the bone using stereotactic body radiation therapy: Is RCC truly radioresistant? Pract Radiat Oncol 5(6): e589-e596, 2015. PMID: 26142027. DOI: 10.1016/j.prro.2015.05.004

68 Zelefsky MJ, Greco C, Motzer R, Magsanoc JM, Pei X, Lovelock M, Mechalakos J, Zatcky J, Fuks Z and Yamada Y: Tumor control outcomes after hypofractionated and single-dose stereotactic image-guided intensity-modulated radiotherapy for extracranial metastases from renal cell carcinoma. Int J Radiat Oncol Biol Phys 82(5): 1744-1748, 2012. PMID: 21596489. DOI: $10.1016 /$ j.ijrobp.2011.02.040

69 Meyer E, Pasquier D, Bernadou G, Calais G, Maroun P, Bossi A, Theodore C, Albiges L, Stefan D, de Crevoisier R, Hennequin C, Lagrange JL, Grellard JM, Clarisse B, Licaj I, Habrand JL, Carrie $\mathrm{C}$ and Joly F: Stereotactic radiation therapy in the strategy of treatment of metastatic renal cell carcinoma: A study of the Getug group. Eur J Cancer 98: 38-47, 2018. PMID: 29864737. DOI: $10.1016 /$ j.ejca.2018.04.008

70 Buti S, Bersanelli M, Viansone A, Leonetti A, Masini C, Ratta R, Procopio G, Maines F, Iacovelli R, Ciccarese C, Vitale MG, De Giorgi U, Mucciarini C, Maruzzo M, Prati G, Lattanzi E,
Ciammella P, Bruni A, Andreani S and D'Abbiero N: Treatment outcome of metastatic lesions from renal cell carcinoma under going extra-cranial stereotactic body radiotherapy: The together retrospective study. Cancer Treat Res Commun 22: 100161, 2020. PMID: 31677494. DOI: 10.1016/j.ctarc.2019.100161

71 De Wolf K, Vermaelen K, De Meerleer G, Lambrecht BN and Ost P: The potential of radiotherapy to enhance the efficacy of renal cell carcinoma therapy. Oncoimmunology 4(10): e1042198, 2015. PMID: 26464810. DOI: 10.1080/2162402X. 2015.1042198

72 Deng L, Liang H, Burnette B, Beckett M, Darga T, Weichselbaum RR and Fu YX: Irradiation and anti-PD-L1 treatment synergistically promote antitumor immunity in mice. J Clin Invest 124(2): 687-695, 2014. PMID: 24382348. DOI: 10.1172/JCI67313

73 Kroon P, Gadiot J, Peeters M, Gasparini A, Deken MA, Yagita $\mathrm{H}$, Verheij M, Borst J, Blank CU and Verbrugge I: Concomitant targeting of programmed death-1 (PD-1) and CD137 improves the efficacy of radiotherapy in a mouse model of human BRAFV600-mutant melanoma. Cancer Immunol Immunother 65(6): 753-763, 2016. PMID: 27160390. DOI: 10.1007/s00262016-1843-4

74 Vanpouille-Box C, Alard A, Aryankalayil MJ, Sarfraz Y, Diamond JM, Schneider RJ, Inghirami G, Coleman CN, Formenti SC and Demaria S: DNA exonuclease Trex1 regulates radiotherapy-induced tumour immunogenicity. Nat Commun 8 : 15618, 2017. PMID: 28598415. DOI: $10.1038 /$ ncomms 15618

75 Buttigliero C, Allis S, Tucci M, Zichi C, Leone G, Di Stefano RF, Ruo Redda MG, Ricardi U, Scagliotti GV, Di Maio M and Filippi AR: Role of radiotherapy in improving activity of immune-modulating drugs in advanced renal cancer: Biological rationale and clinical evidences. Cancer Treat Rev 69: 215-223, 2018. PMID: 30096699. DOI: 10.1016/j.ctrv.2018.07.010

76 Alexander GS, Palmer JD, Tuluc M, Lin J, Dicker AP, Bar-Ad V, Harshyne LA, Louie J, Shaw CM, Hooper DC and Lu B: Immune biomarkers of treatment failure for a patient on a phase I clinical trial of pembrolizumab plus radiotherapy. J Hematol Oncol 9(1): 96, 2016. PMID: 27663515. DOI: 10.1186/s13045016-0328-4

77 Masini C, Iotti C, De giorgi U, Bellia R, Buti S, Salaroli F, Zampiva I, Mazzarotto R, Mucciarini C, Baldessari C, Bruni A, Procopio G, Kinspergher S, Nole F, Morelli F, Baier S, Buttigliero C, Berselli A and Pinto C: Nivolumab (NIVO) in combination with stereotactic body radiotherapy (SBRT) in pretreated patients (pts) with metastatic renal cell carcinoma (mRCC): First results of phase II Nives study. Journal of Clinical Oncology 38(6_suppl): 613-613，2020. DOI: 10.1200/ JCO.2020.38.6_suppl.613

78 Hammers H, Vonmerveldt D, Ahn C, Nadal R, Drake C, Folkert M, Laine A, Courtney K, Brugarolas J, Song D, Hannan R and Carducci M: Combination of dual immune checkpoint inhibition (ICI) with stereotactic radiation (SBRT) in metastatic renal cell carcinoma (mRCC) (RADVAX RCC). Journal of Clinical Oncology 38(6_suppl): 614-614, 2020. DOI: 10.1200/JCO.2020. 38.6_suppl.614

79 Xin H, Zhang C, Herrmann A, Du Y, Figlin R and Yu H: Sunitinib inhibition of Stat3 induces renal cell carcinoma tumor cell apoptosis and reduces immunosuppressive cells. Cancer Res 69(6): 2506-2513, 2009. PMID: 19244102. DOI: 10.1158/00085472.CAN-08-4323 
80 Staehler M, Haseke N, Nuhn P, Tüllmann C, Karl A, Siebels M, Stief CG, Wowra B and Muacevic A: Simultaneous antiangiogenic therapy and single-fraction radiosurgery in clinically relevant metastases from renal cell carcinoma. BJU Int 108(5): 673-678, 2011. PMID: 21156017. DOI: 10.1111/j.1464410X.2010.09895.x

81 Tong CC, Ko EC, Sung MW, Cesaretti JA, Stock RG, Packer SH, Forsythe K, Genden EM, Schwartz M, Lau KH, Galsky M, Ozao-Choy J, Chen SH and Kao J: Phase II trial of concurrent sunitinib and image-guided radiotherapy for oligometastases. PLoS One 7(6): e36979, 2012. PMID: 22761653. DOI: 10.1371/journal.pone.0036979

82 Kao J, Chen C, Tong C, Packer S, Schwartz M, Chen S and Sung M: Concurrent sunitinib and stereotactic body radiotherapy for patients with oligometastases. Targeted Oncology 9(2): 145153, 2019. DOI: 10.1007/s11523-013-0280-y

83 Kusuda Y, Miyake H, Terakawa T, Furukawa J, Muramaki M and Fujisawa M: Treatment of brain metastases from renal cell carcinoma with sunitinib and radiotherapy: Our experience and review of the literature. Int J Urol 18(4): 326-329, 2011. PMID: 25522450. DOI: $10.1111 / \mathrm{j} .1442-2042.2010 .02706 . x$
84 Miller JA, Balagamwala EH, Angelov L, Suh JH, Rini B, Garcia JA, Ahluwalia M and Chao ST: Spine stereotactic radiosurgery with concurrent tyrosine kinase inhibitors for metastatic renal cell carcinoma. J Neurosurg Spine 25(6): 766-774, 2016. PMID: 27391397. DOI: $10.3171 / 2016.4$.SPINE16229

85 He L, Liu Y, Han H, Liu Z, Huang S, Cao W, Liu B, Qin Z, Guo S, Zhang Z, Lin M, Jiang X, Lin C, Li Y, Yao K, Dong P and Zhou F: Survival outcomes after adding stereotactic body radiotherapy to metastatic renal cell carcinoma patients treated with tyrosine kinase inhibitors. Am J Clin Oncol 43(1): 58-63, 2020. PMID: 31651452 . DOI: 10.1097/COC.0000000000000622

86 Siva S, Kothari G, Muacevic A, Louie AV, Slotman BJ, Teh BS and Lo SS: Radiotherapy for renal cell carcinoma: Renaissance of an overlooked approach. Nat Rev Urol 14(9): 549-563, 2017. PMID: 28631740. DOI: 10.1038/nrurol.2017.87

Received September 16, 2020

Revised March 26, 2021

Accepted March 31, 2021 